\title{
Asenapine Increases Dopamine, Norepinephrine, and Acetylcholine Efflux in the Rat Medial Prefrontal Cortex and Hippocampus
}

\author{
Mei Huang ${ }^{1,2}$, Zhu Li ${ }^{1,2}$, Jin Dai' ${ }^{1,2}$, Mohammed Shahid ${ }^{3}$, Erik HF Wong ${ }^{4}$ and Herbert Y Meltzer*,1,2 \\ 'Department of Psychiatry, Division of Psychopharmacology, Vanderbilt University School of Medicine, Nashville, TN, USA; ${ }^{2}$ Department of \\ Pharmacology, Division of Psychopharmacology, Vanderbilt University School of Medicine, Nashville, TN, USA; ${ }^{3}$ Organon Laboratories Ltd, \\ Lanarkshire, UK; ${ }^{4}$ Pfizer Global R\&D, Ann Arbor, MI, USA
}

\begin{abstract}
Atypical antipsychotic drugs, which are more potent direct acting antagonists of brain serotonin $(5-H T)_{2 A}$ than dopamine $(\mathrm{DA}) \mathrm{D}_{2}$ receptors, preferentially enhance DA and acetylcholine (ACh) efflux in the rat medial prefrontal cortex (mPFC) and hippocampus (HIP), compared with the nucleus accumbens (NAc). These effects may contribute to their ability, albeit limited, to improve cognitive function and negative symptoms in patients with schizophrenia. Asenapine (ASE), a new multireceptor antagonist currently in development for the treatment of schizophrenia and bipolar disorder, has complex serotonergic properties based upon relatively high affinity for multiple serotonin $(5-H T)$ receptors, particularly $5-\mathrm{HT}_{2 \mathrm{~A}}$ and $5-\mathrm{HT}_{2 \mathrm{C}}$ receptors. In the current study, the effects of ASE on DA, norepinephrine (NE), 5-HT, ACh, glutamate, and $\gamma$-aminobutyric acid (GABA) efflux in rat mPFC, HIP, and NAc were investigated with microdialysis in awake, freely moving rats. ASE at $0.05,0.1$, and $0.5 \mathrm{mg} / \mathrm{kg}$ (s.c.), but not $0.01 \mathrm{mg} / \mathrm{kg}$, significantly increased DA efflux in the mPFC and HIP. Only the $0.5 \mathrm{mg} / \mathrm{kg}$ dose enhanced DA efflux in the NAc. ASE, at 0.1 and $0.5 \mathrm{mg} / \mathrm{kg}$, significantly increased ACh efflux in the mPFC, but only the $0.5 \mathrm{mg} / \mathrm{kg}$ dose of ASE increased HIP ACh efflux. ASE did not increase ACh efflux in the NAc at any of the doses tested. The effect of ASE $(0.1 \mathrm{mg} / \mathrm{kg})$ on DA and ACh efflux was blocked by pretreatment with WAYI00635, a 5-HTIA antagonist/D 4 agonist, suggesting involvement of indirect $5-\mathrm{HT}_{\mathrm{IA}}$ agonism in both the actions. ASE, at $0.1 \mathrm{mg} / \mathrm{kg}$, increased NE, but not 5-HT, efflux in the mPFC and HIP. ASE, at $0.1 \mathrm{mg} / \mathrm{kg}$ (s.c.), had no effect on glutamate and GABA efflux in either the mPFC or NAc. These findings indicate that ASE is similar to clozapine and other atypical antipsychotic drugs in preferentially increasing the efflux of DA, NE, and ACh in the mPFC and HIP compared with the NAC, and suggests that, like these agents, it may also improve cognitive function and negative symptoms in patients with schizophrenia.

Neuropsychopharmacology (2008) 33, 2934-2945; doi:I0.I038/npp.2008.20; published online 16 April 2008
\end{abstract}

Keywords: acetylcholine; asenapine; dopamine; glutamate; norepinephrine; rat brain

\section{INTRODUCTION}

Atypical antipsychotics differ from conventional antipsychotic drugs in that they cause fewer extrapyramidal symptoms (EPS), do not produce sustained elevations of serum prolactin levels (with the exception of risperidone and paliperidone), and can improve some domains of cognition in patients with schizophrenia (Meltzer and McGurk, 1999; Harvey and Keefe, 2001; Woodward et al, 2005; Keefe et al, 2007). The basis for the cognitive impairment in schizophrenia is complex; it has principally

*Correspondence: Dr HY Meltzer, The Psychiatric Hospital at Vanderbilt, I60I 23rd Avenue South, Suite 306, Nashville, TN 372 12, USA, Tel: + | 615327 7049, Fax: + | 6153277093 ,

E-mail: herbert.meltzer@vanderbilt.edu

Received 31 October 2007; revised 22 January 2008; accepted 24 January 2008 been related to diminished or dysregulated brain dopaminergic (Weinberger et al, 1988), noradrenergic (Arnsten and $\mathrm{Li}, 2005$ ), cholinergic (Meltzer and McGurk, 1999; Bymaster et al, 2002), glutamatergic (Hirsch et al, 1997), and $\gamma$-aminobutyric acid (GABA) activity (Benes and Berretta, 2000), to neuronal or neuropil loss (Selemon and GoldmanRakic, 1999), and to abnormalities in connectivity (Pantelis et al, 1997; Nakamura et al, 2005). Thus, the ability of atypical antipsychotic drugs to preferentially increase extracellular efflux of dopamine (DA), norepinephrine $(\mathrm{NE})$, and acetylcholine (ACh) in the medial prefrontal cortex (mPFC) and hippocampus (HIP) has been postulated to contribute to their ability to improve cognition, in schizophrenia, and possibly negative symptoms and depression (Assie et al, 2005; Devoto et al, 2004; Ichikawa et al, 1998; Ichikawa et al, 2002a, b, c; Kuroki et al, 1999; Zhang et al, 2000). The effects of atypical antipsychotic drugs on glutamatergic transmission has also been suggested to 
contribute to their ability to improve cognitive impairment in schizophrenia (Konradi and Heckers, 2003; Coyle, 2006). Acute treatment with clozapine has been reported to enhance extracellular glutamate levels while decreasing GABA efflux in the rat mPFC, in some but not all studies (Bourdelais and Deutch, 1994; Daly and Moghaddam, 1993; Yamamoto et al, 1994; Yamamoto and Cooperman, 1994; Heidbreder et al, 2001). Olanzapine, however, at $5 \mathrm{mg} / \mathrm{kg}$, had no effect on the extracellular levels of glutamate, whereas clozapine, at $10 \mathrm{mg} / \mathrm{kg}$, significantly increased extracellular glutamate levels in the same study (Heidbreder et al, 2001). Haloperidol has also been reported to decrease extracellular GABA efflux from interneurons in the mPFC (Bourdelais and Deutch, 1994).

Asenapine (ASE) (Org 5222; trans-5-chloro-2-methyl2,3,3a,12b-tetrahydro-1H-dibenz $[2,3: 6,7,5]$-oxepino-[4,5c] pyrrolidine maleate) is a putative atypical antipsychotic drug (Broekkamp et al, 1990; Bymaster et al, 1996; Costall et al, 1990; De Boer et al, 1990, 1993; Shahid et al, 2007) currently being developed for the treatment of schizophrenia and bipolar disorder (Alphs et al, 2007). Potkin et al (2007) have recently reported that ASE improves positive and negative symptoms in patients with schizophrenia at least as effectively as risperidone (Potkin et al, 2007).

In vitro and in vivo receptor binding studies have shown that ASE has high affinities for multiple monoamine receptors, including (1) $\mathrm{D}_{1,2,3}$ and $\mathrm{D}_{4}$; (2) 5- $\mathrm{HT}_{2 \mathrm{~A}}, 2 \mathrm{C}, 1 \mathrm{~A}, 1 \mathrm{~B}, 2 \mathrm{~B}, 5 \mathrm{~A}, 6,7$; (3) adrenergic $\alpha_{1 \mathrm{~A}}$ and $\alpha_{2 \mathrm{~A}, 2 \mathrm{~B}, 2 \mathrm{C}}$; and (4) histamine $\mathrm{H}_{1}$ and $\mathrm{H}_{2}$ receptors, but that it lacks affinity for muscarinic receptors (Bymaster et al, 1996; Cosi and Koek, 2001; Matsubara et al, 1993; Prinssen et al, 2000; Richelson and Souder, 2000; Schotte et al, 1996; Shahid et al, 2007). In vitro assessments have shown that ASE is an antagonist at all of the monoamine receptors listed above (Shahid et al, 2007). ASE has approximately 20-fold higher affinity for $5-\mathrm{HT}_{2 \mathrm{~A}}$ compared with DA $\mathrm{D}_{2}$ receptors (De Boer et al, 1993; Schotte et al, 1996; Shahid et al, 2007). Shahid et al (2007) reported the $\mathrm{p} K_{\mathrm{i}}$ for ASE for the $5-\mathrm{HT}_{2 \mathrm{~A}}$ receptor as 10.15 , and for the D2L, 8.90, using cloned human receptors stably expressed in mammalian cell lines. The occupancy in the rat brain of cortical $5-\mathrm{HT}_{2 \mathrm{~A}}$ receptors by ASE is also about 20fold higher than that of striatal $\mathrm{D}_{2}$ receptors (Schotte et al, 1996). The relatively high occupancy of $5-\mathrm{HT}_{2 \mathrm{~A}}$ compared with the $\mathrm{D}_{2}$ receptor may be critically important for some atypical antipsychotic drug actions, such as low EPS and efficacy in treatment-resistant schizophrenia (Meltzer et al, $1989,2003,2008)$. This profile has also been proposed as an important component of the preferential release of cortical DA by relatively specific ligands for these receptors, for example, M 100907, SR 43469B, or ACP-103, and haloperidol (Liegeois et al, 2002; Bonaccorso et al, 2002; Li et al, 2005), as well as clozapine, olanzapine, risperidone, and other atypical antipsychotic drugs, which are more potent $5-\mathrm{HT}_{2 \mathrm{~A}}$ than $\mathrm{D}_{2}$ antagonists (Kuroki et al, 1999).

The ability of WAY100635, a silent 5- $\mathrm{HT}_{1 \mathrm{~A}}$ antagonist and $\mathrm{D}_{4}$ agonist (Chemel et al, 2006), to block most or all of the ability of the atypical antipsychotic drugs to enhance cortical DA (Ichikawa et al, 2001; Li et al, 2004), as well as, for some, for example, quetiapine, ACh efflux (Ichikawa et al, 2002a, c; Sato et al, 2007), suggests that these effects of the atypical antipsychotic drugs are due in part to indirect or direct $5-\mathrm{HT}_{1 \mathrm{~A}}$ agonism (Ichikawa et al, 2001; Meltzer et al, 2003; Li et al, 2004). Risperidone and olanzapine are atypical antipsychotic drugs whose effects on cortical DA efflux are blocked by WAY100635, but which themselves are not $5-\mathrm{HT}_{1 \mathrm{~A}}$ agonists. Aripiprazole, bifeprunox, clozapine, quetiapine, and ziprasidone, on the other hand, are $5-\mathrm{HT}_{1 \mathrm{~A}}$ partial agonists (Cosi and Koek, 2001). We, therefore, sought to characterize the effect of WAY100635 on ASEinduced increases in DA and ACh efflux in mPFC. We also sought to characterize the effect of ASE on the efflux of cortical 5-HT, glutamate, and GABA, as there are limited data on the ability of atypical antipsychotic drugs to affect the efflux of these important neurotransmitters.

\section{MATERIALS AND METHODS}

\section{Animals}

Male Sprague-Dawley albino rats (Zivic-Miller Laboratories, Porterville, PA) weighing 250-300 g were used throughout the study. They were housed two per cage in a controlled 12:12-h light-dark cycle under constant temperature at $22^{\circ} \mathrm{C}$, with free access to food and water.

\section{Surgery and Microdialysis}

Rats were anesthetized with a combination of intraperitoneal chloral hydrate $(172 \mathrm{mg} / \mathrm{kg})$ and pentobarbital $(35.6 \mathrm{mg} / \mathrm{kg})$, and mounted in a stereotaxic frame (Stoetling, Wood Dale, IL). A stainless steel guide cannula $(21 \mathrm{G})$ with a dummy probe was placed and fixed by cranioplastic cement (Plastics One, Roanoke, VA) onto the cortex, dorsal to the mPFC. The stereotaxic coordinates for the implanted probe were A, $+3.2 \mathrm{~mm}$; $\mathrm{L},-0.8 \mathrm{~mm}\left(10^{\circ}\right.$ inclination); $\mathrm{V},-5.5 \mathrm{~mm}$, relative to the bregma. The coordinates for HIP and nucleus accumbens (NAc) were A, $-5.6 \mathrm{~mm}$; $\mathrm{L},+5 \mathrm{~mm} ; \mathrm{V},-7 \mathrm{~mm}$; and $\mathrm{A},+2 \mathrm{~mm} ; \mathrm{L},+1.5 \mathrm{~mm}$; $\mathrm{V},-7.5 \mathrm{~mm}$, respectively. The incisor bar level was $-3 \mathrm{~mm}$, according to the atlas of Paxinos and Watson (1986). Concentric-shaped dialysis probes were constructed as described elsewhere (Ichikawa et al, 2001). A hollow-fiber dialysis membrane (polyacrylonitrile/sodium methylsulfonate polymer, $310 \mu \mathrm{m}$, o.d., $220 \mu \mathrm{m}$, i.d., molecular weight cut-off $40000 \mathrm{Da}$; AN69 HF; Hôpital SA, Lyon, France) was used, with $2 \mathrm{~mm}$ of non-glued surface exposed for dialyzing. A total of 3-5 days after cannulation, dual dialysis probes were implanted into the rat $\mathrm{mPFC}$ and HIP/NAc under light anesthesia with methylsulfonate (Metofane; Pitman-Moore, Mundelein, IL). For systemic administration of drugs or the vehicle, a microbore Tygon tubing (TGY-010, 0.03 inches, o.d., 0.01 inches, i.d.; Small Parts Inc., Miami Lakes, FL) catheter was implanted subcutaneously into the intrascapular space. Rats were then housed individually in dialysis cages, with overnight perfusion $(0.3 \mu \mathrm{l} / \mathrm{min})$ of the probe, with the perfusion rate increased to $1.5 \mu \mathrm{l} / \mathrm{min}$ on the morning of the day of dialysis. After $1 \mathrm{~h}$ of perfusion at $1.5 \mu \mathrm{l} / \mathrm{min}$, dialysate samples were collected every $30 \mathrm{~min}$ for measuring dialysate neurotransmitter concentrations. The perfusion medium was Dulbecco's phosphate-buffered saline solution (Sigma, St Louis, MO), including $\mathrm{Ca}^{2+}$ (138 mM NaCl, 8.1 mM Na $\mathrm{HPO}_{4}, 2.7 \mathrm{mM} \mathrm{KCl}, 1.5 \mathrm{mM}$ $\mathrm{KH}_{2} \mathrm{PO} 4,0.5 \mathrm{mM} \mathrm{MgCl}, 1.2 \mathrm{mM} \mathrm{CaCl}_{2}, \mathrm{pH}=7.4$ ). After stable baseline values were obtained in the dialysates, each 
drug or vehicle was administered subcutaneously. The effect of the drug on neurotransmitter release was monitored for another $180 \mathrm{~min}$. Locations of dialysis probes were verified at the end of each experiment by manual brain dissection and using $100-\mu \mathrm{m}$ brain slices (OTS-4000; FHC Inc., Bowdoinham, ME). The procedures used in this experiment were approved by the Institutional Animal Care and Use Committee of Vanderbilt University, Nashville, TN.

\section{Biochemical Assays}

$D A, N E$, serotonin, and ACh analysis. All samples were directly applied onto a high-performance liquid chromatography (HPLC) system with electrochemical detection. DA and NE were simultaneously separated on a reversed-phase column (Xtera RP18, $3 \mu \mathrm{m}, 2.1 \times 100 \mathrm{~mm}$; Waters Co., Milford, MA). The mobile phase consisted of buffer (24 mM anhydrous citric acid, $48 \mathrm{mM}$ sodium acetate trihydrate, $2 \mathrm{mM}$ sodium dodecylsulfate, $0.5 \mathrm{mM}$ EDTA$2 \mathrm{Na}$ ), acetonitrile, and methanol in a ratio of $88: 8: 4$, respectively, and adjusted to $\mathrm{pH} 4.8$ with sodium hydroxide. The flow rate was $0.3 \mathrm{ml} / \mathrm{min}$. The potentials for Coulochem microdialysis electrode (ESA 5014B; ESA Biosciences Inc., Chelmsford, MA) were $-100 \mathrm{mV}$ and $180 \mathrm{mV} v s$ an $\mathrm{Ag} / \mathrm{AgCl}$ reference electrode. The retention times for $\mathrm{NE}$ and $\mathrm{DA}$ were 4.6 and $13 \mathrm{~min}$, respectively. The method for determination of dialysate 5-HT has been described previously (Ichikawa et al, 1998). The method for determination of dialysate $\mathrm{ACh}$, without addition of a cholinesterase inhibitor, has been described previously (Ichikawa et al, 2002b).

Glutamate and GABA analysis. The stock-derivatizing agent OPA (o-phthalaldehyde, $3.0 \mathrm{mg}$; Sigma-Aldrich, St Louis, MO) was dissolved in $140 \mu \mathrm{l}$ absolute ethanol (HPLC grade), to which was added $140 \mu \mathrm{l}$ sodium sulfite $\left(\mathrm{Na}_{2} \mathrm{SO}_{3}\right.$, $1 \mathrm{mM})$ and $2.4 \mathrm{ml}$ of sodium tetraborate buffer at $\mathrm{pH} 10.4$ $\left(\mathrm{NaBH}_{4}, 1 \mathrm{mM}\right)$. The working OPA consisted of $0.5 \mathrm{ml}$ stock OPA, $0.5 \mathrm{ml} \mathrm{Na} \mathrm{SO}_{3}$, and $4 \mathrm{ml} \mathrm{NaBH} 4$ (pH 10.4). $\beta$-Aminobutyric acid dissolved in water constituted the internal standard. The reaction of $5 \mu$ internal standard, $20 \mu \mathrm{l}$ sample, and $5 \mu \mathrm{l}$ working OPA solution proceeded at room temperature for $30 \mathrm{~min}$ before injection into the HPLC system. The column system consisted of a small column (XTrra reverse-phase C18, $2.1 \times 10 \mathrm{~mm}$, column A; Waters Co.) and a main reverse-phase column (Nova-Pak C18, $3.9 \times 300 \mathrm{~mm}, 5 \mu \mathrm{m}$, column B; Waters Co.) kept at $36^{\circ} \mathrm{C}$ when in use. The mobile phase consisted of $83.5 \%(\mathrm{v} /$ v) of buffer $(0.1 \mathrm{M}$ sodium dihydrogen phosphate dehydrate, $2 \mathrm{mM}$ tetrabutylammonium phosphate, and $1 \mathrm{mM}$ EDTA, adjusted to $\mathrm{pH} 4$ with $1 \mathrm{M}$ phosphoric acid) and $16.5 \%$ of acetonitrile, perfused at a flow rate of $0.9 \mathrm{ml} / \mathrm{min}$ by a gradient liquid chromatograph pump (LC-10AD; Shimadzu Corp., Kyoto, Japan). A high-density glassy carbon working electrode combined with an $\mathrm{Ag} / \mathrm{AgCl}$ reference electrode was operated at $+0.58 \mathrm{~V}$. A Rheodyne injection valve with a 20- $\mu$ l sample loop with auto-sampler was used to inject the samples. Column A was outside the main system and perfused by mobile phase at $0.1 \mathrm{ml} / \mathrm{min}$, with a Waters HPLC pump. At sample injection, the flow rate was raised to $0.25 \mathrm{ml} / \mathrm{min}$, and $45 \mathrm{~s}$ later the small column was connected to main column B for a minute.
Column A was then isolated and perfused with $50 \%$ buffer and $50 \%$ acetonitrile for $10 \mathrm{~min}$, and eluted with the mobile phase for a further $5 \mathrm{~min}$. The flow rate of column A was then decreased to $0.1 \mathrm{ml} / \mathrm{min}$, prior to the next sample injection.

\section{Drugs}

ASE (Org 5222; trans-5-chloro-2-methyl-2,3,3a,12b-tetrahydro-1H-dibenz[2,3:6,7,5]-oxepino-[4,5c]pyrrolidine maleate; Organon, Lanarkshire, UK) and the $5-\mathrm{HT}_{1 \mathrm{~A}}$ blocker WAY100635 (Wyeth, Philadelphia, PA) were dissolved in deionized water. Vehicle or drug was administered subcutaneously through the implanted catheter in a volume of $1 \mathrm{ml} / \mathrm{kg}$. WAY100635 was given $30 \mathrm{~min}$ prior to ASE. The doses of ASE were selected based on published in vivo behavioral and receptor studies (De Boer et al, 1993; Schotte et al, 1996).

\section{Data Analysis}

All dialysis probe placements were checked after killing the rats. Only results derived from rats with correctly positioned probes were included in the data analysis. Three rats, which were sedated following surgery, were not studied. The mean value of three consecutive stable samples prior to drug injection was set at $100 \%$ and considered the predrug basal level. Basal extracellular levels of each neurotransmitter in the MPFC, HIP, and NAC were compared by one-way analysis of variance (ANOVA). The time-dependent effect of drugs on each neurotransmitter in the three regions was analyzed using a repeated-measure ANOVA, with treatment group as a fixed factor and time as the within-subject factor. The response area under the curve (AUC) was calculated by the trapezoid rule, using data following injection of the vehicle or drug. Two-way ANOVA was used to compare the effect of treatment on AUC for each neurotransmitter across the three regions. ANOVA was followed by the least-square significant difference post hoc pairwise comparison procedure. The level of significance was set at $p<0.05$. All analyses were performed using SAS ${ }^{\mathrm{TM}}$ (SAS Institute Inc., Cary, NC, USA) statistical software.

\section{RESULTS}

Baseline Extracellular DA, NE, Serotonin, ACh, Glutamate, and GABA Levels in the Cortex, HIP, and NAc

One-way ANOVA showed no significant differences among the treatment groups regarding baseline extracellular DA, $\mathrm{ACh}, \mathrm{NE}, 5-\mathrm{HT}$, glutamate, and GABA levels in the three brain regions studied. Baseline extracellular DA levels in all rats in this study were $0.12 \pm 0.02 \mathrm{nM}$ in the $\mathrm{mPFC}(\mathrm{F}=1.16$, $p=0.36, n=38), \quad 0.15 \pm 0.03 \mathrm{nM}$ in the HIP $(\mathrm{F}=2.70$, $p=0.08, n=38)$, and $0.75 \pm 0.06 \mathrm{nM}$ in the NAc $(\mathrm{F}=2.24$, $p=0.16, n=20)$. Baseline NE levels were $0.19 \pm 0.03 \mathrm{nM}$ in the $\mathrm{mPFC}(\mathrm{F}=0.84, p=0.46, n=20)$ and $0.12 \pm 0.02 \mathrm{nM}$ in the HIP $(\mathrm{F}=2.64, p=0.09, n=19)$. Baseline 5-HT levels in the dialysates were $0.12 \pm 0.01 \mathrm{nM}$ in the $\mathrm{mPFC}(\mathrm{F}=2.32$, $p=0.18, n=15)$ and $0.13 \pm 0.02 \mathrm{nM}$ in the HIP $(\mathrm{F}=1.77$, $p=0.24, n=15)$. Baseline ACh levels were $0.58 \pm 0.14 \mathrm{nM}$ in 
the $\mathrm{mPFC}(\mathrm{F}=2.77, p=0.08, n=28), 0.47 \pm 0.09 \mathrm{nM}$ in the HIP ( $\mathrm{F}=3.00, p=0.10, n=23)$, and $0.44 \pm 0.17 \mathrm{nM}$ in the NAc $(\mathrm{F}=1.76, p=0.24, n=21)$. Baseline extracellular glutamate levels were $2.38 \pm 0.60 \mu \mathrm{M}$ in the $\mathrm{mPFC}$ $(\mathrm{F}=0.85, p=0.40)$ and $2.46 \pm 0.67 \mu \mathrm{M}$ in the NAc $(\mathrm{F}=1.69, p=0.26$, both $n=10)$. Baseline GABA levels were $0.04 \pm 0.01 \mu \mathrm{M}$ in the $\operatorname{mPFC}(\mathrm{F}=0.57, p=0.48)$ and $0.05 \pm 0.01 \mu \mathrm{M}$ in the NAc $(\mathrm{F}=0.35, p=0.58$, both $n=10)$. Vehicle administration did not affect extracellular baseline levels of these neurotransmitters, in these regions.

\section{Effect of ASE on DA Efflux in the MPFC, HIP, and NAc}

ASE increased extracellular DA in the MPFC, HIP, and NAC (Figure 1). Repeated-measure ANOVA of mPFC data showed significant overall group $(\mathrm{F}=7.31, p=0.0001)$ and time effects $(F=2.66, p=0.02)$. The group $\times$ time effect was not significant. Post hoc analysis revealed that ASE at $0.05 \mathrm{mg} / \mathrm{kg}$ $(p=0.004)$, ASE at $0.1 \mathrm{mg} / \mathrm{kg}(p=0.005)$, and ASE at $0.5 \mathrm{mg} /$ $\mathrm{kg}(p=0.0003)$ were significantly different from the vehicle, whereas ASE at $0.01 \mathrm{mg} / \mathrm{kg}$ differed from the higher doses but not the vehicle. For the HIP, both overall group $(\mathrm{F}=4.32, p=0.01)$ and time $(\mathrm{F}=2.40, p=0.03)$ effects were significant, but the group $\times$ time interaction was not. Post hoc analysis showed that ASE at $0.05 \mathrm{mg} / \mathrm{kg}(p=0.03)$ and ASE at $0.5 \mathrm{mg} / \mathrm{kg}(p=0.004)$ differed significantly from the vehicle; ASE at $0.1 \mathrm{mg} / \mathrm{kg}$ differed at the trend level $(p=0.09) ;$ ASE at $0.01 \mathrm{mg} / \mathrm{kg}$ did not differ from the vehicle, but was significantly different from the other doses studied. For the NAc, the group $\times$ time interaction was significant $(\mathrm{F}=1.84, p=0.03)$. The time effect was not significant, but the overall group effect was $(\mathrm{F}=5.93, p=0.01)$. Post hoc analysis revealed that ASE at $0.5 \mathrm{mg} / \mathrm{kg}$ was significantly different from the vehicle $(p=0.002)$, ASE at $0.1 \mathrm{mg} / \mathrm{kg}$ $(p=0.005)$, and ASE at $0.05 \mathrm{mg} / \mathrm{kg}(p=0.01)$. The response AUC (Figure 1) was significantly different among the treatment groups for each region, $\operatorname{mPFC}(\mathrm{F}=6.99$, $p=0.001)$, HIP $(\mathrm{F}=4.69, p=0.007)$, and NAC $(\mathrm{F}=5.70$, $p=0.01)$. Post hoc analysis showed essentially the same group differences within region as the repeated-measure ANOVA reported above. $P$-values for differences among the response AUCs are given in the legend to Figure 1.

Two-way ANOVA was used to compare the treatment group across the three regions. The interaction of region and treatment was not significant. The main effects of region, regardless of dose $(\mathrm{F}=3.20, p=0.05)$, and treatment group, regardless of region $(\mathrm{F}=15.35, p=0.0001)$, were significant. ASE at $0.05 \mathrm{mg} / \mathrm{kg}(p=0.03)$ and ASE at $0.1 \mathrm{mg} /$
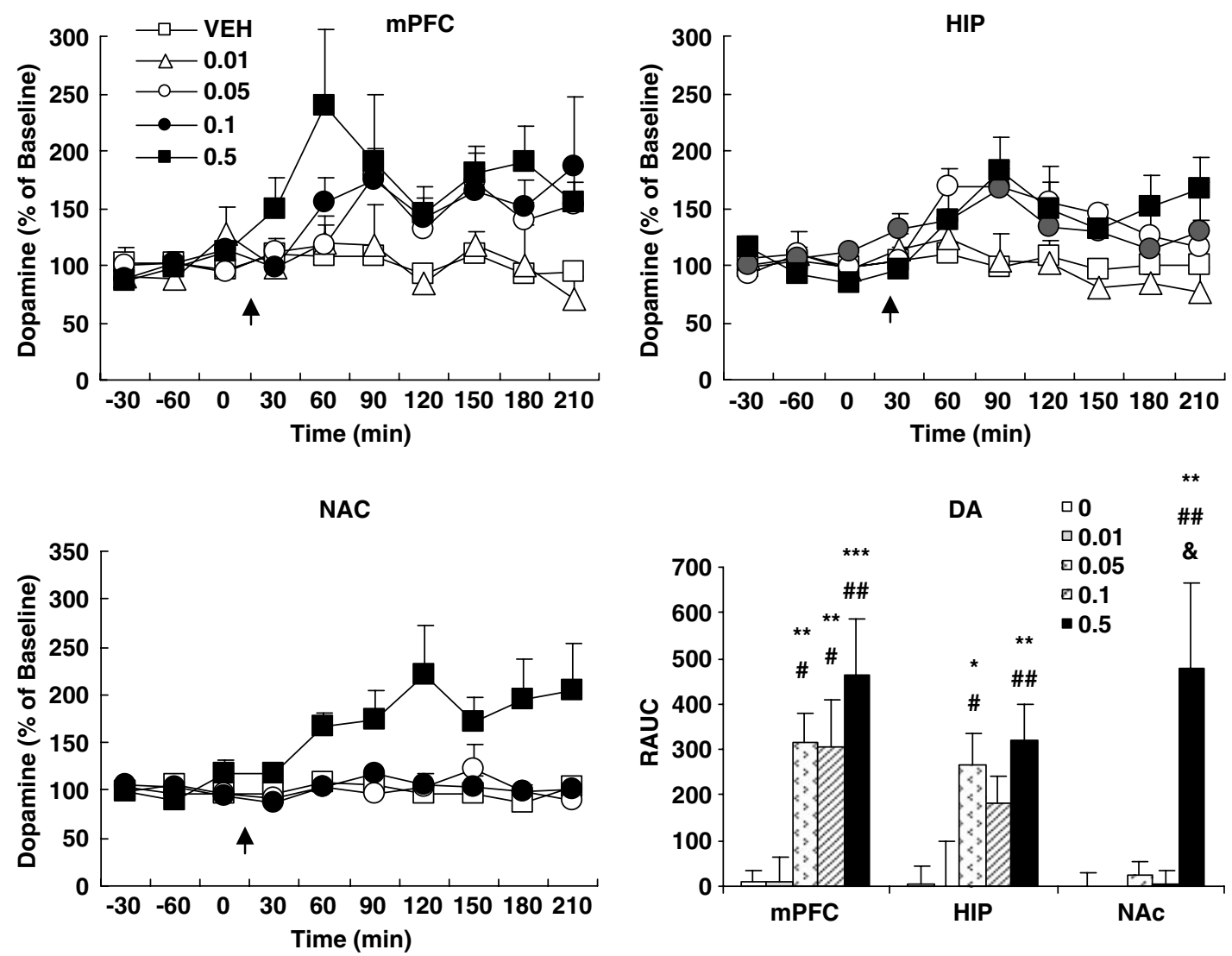

Figure I Effect of ASE (0.0I, 0.05, 0.1 , and $0.5 \mathrm{mg} / \mathrm{kg}, \mathrm{s.c}$.$) on DA efflux in rat mPFC, HIP, and NAc. Data are mean \pm$ SEM of the dialysate DA levels, expressed as a percentage of the baseline. The response AUC (RAUC) was significantly different among the treatment groups for each region: $\mathrm{mPFC}$ $(F=6.99, p=0.00 \mathrm{I}), \mathrm{HIP}(\mathrm{F}=4.69, p=0.007)$, and NAc $(F=5.70, p=0.0 \mathrm{I})$. For the mPFC, post hoc analysis revealed that the ASE $0.05 \mathrm{mg} / \mathrm{kg}(p=0.004)$, and ASE $0.5 \mathrm{mg} / \mathrm{kg}(p=0.0003)$ groups were significantly different from vehicle. Also, ASE at $0.1 \mathrm{mg} / \mathrm{kg}$, was significantly different from ASE at $0.5 \mathrm{mg} / \mathrm{kg}$ $(p=0.0003)$. For the HIP, both ASE at $0.05 \mathrm{mg} / \mathrm{kg}(p=0.0 \mathrm{I})$ and ASE at $0.5 \mathrm{mg} / \mathrm{kg}(p=0.003)$ were significantly different from the vehicle and ASE at $0.01 \mathrm{mg} / \mathrm{kg}(p=0.02, p=0.003)$, respectively. For the NAc, ASE at $0.5 \mathrm{mg} / \mathrm{kg}$ was significantly different from the vehicle group $(p=0.002)$, ASE at $0.05 \mathrm{mg} / \mathrm{kg}$

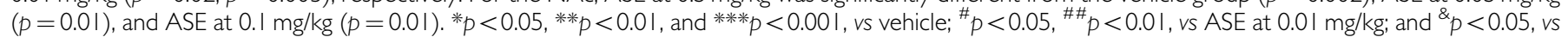
ASE at $0.05 \mathrm{mg} / \mathrm{kg}$. VEH, vehicle. 
$\mathrm{kg}(p=0.02)$, but not ASE at $0.5 \mathrm{mg} / \mathrm{kg}(p=0.09)$, produced greater increases on DA efflux in the MPFC compared with in the NAC; there were no differences between the effects of ASE on DA efflux in the mPFC and HIP at any of the doses studied.

\section{Effects of ASE on ACh Efflux in the mPFC, HIP, and NAc}

ASE increased extracellular ACh in the MPFC and HIP but not in the NAC (Figure 2). Repeated-measure ANOVA of $\mathrm{mPFC} A C h$ data showed significant overall group $(\mathrm{F}=7.94$, $p=0.0004)$ and time effects $(\mathrm{F}=2.43, p=0.03)$. The group $\times$ time effect was not significant. Post hoc analysis revealed that ASE at $0.05 \mathrm{mg} / \mathrm{kg}(p=0.04)$, ASE at $0.1 \mathrm{mg} / \mathrm{kg}$ $(p=0.00)$, and ASE at $0.5 \mathrm{mg} / \mathrm{kg}(p=0.002)$ were significantly different from the vehicle, whereas ASE at $0.01 \mathrm{mg} / \mathrm{kg}$ differed from the higher doses, but not the vehicle. For the HIP, both the overall group $(\mathrm{F}=3.43, p=0.03)$ and time $(\mathrm{F}=3.44, p=0.004)$ effects were significant, but the grouptime interaction was not. Post-hoc analysis showed that ASE at $0.5 \mathrm{mg} / \mathrm{kg}$ differed significantly from the vehicle $(p=0.005)$, from ASE at $0.01 \mathrm{mg} / \mathrm{kg}(p=0.01)$, and ASE at $0.05 \mathrm{mg} / \mathrm{kg}(p=0.04)$. The response AUC (Figure 2) was significantly different among the treatment groups for each region, $\mathrm{mPFC}(\mathrm{F}=7.02, p=0.001)$ and $\mathrm{HIP}(\mathrm{F}=3.99$, $p=0.02$ ) but not the NAC. Post hoc analysis showed essentially the same group differences within region as the repeated-measure ANOVA reported above. P-values for differences among the response AUCs within regions are given in the legend to Figure 2.

Two-way ANOVA was used to compare the treatment groups in the MPFC and HIP. The interaction of region and treatment was not significant. The main effect of group (dose), was significant for both regions $(\mathrm{F}=10.08$, $p=0.0001)$. There was no significant effect for region at any of the doses studied.

\section{Effect of Pretreatment with WAY100635 on ASE- Induced DA and ACh Release in the MPFC and HIP}

WAY100635 (0.2 mg/kg, s.c.) alone had no significant effect on DA or ACh efflux in the mPFC or the HIP (Figure 3). Pretreatment with WAY100635 significantly attenuated the increased DA efflux induced by ASE at $0.1 \mathrm{mg} / \mathrm{kg}$ in both the $\operatorname{mPFC} \quad\left(\mathrm{F}_{1,9}=20.56, P<0.001\right)$ and $\mathrm{HIP} \quad\left(\mathrm{F}_{1,9}=8.47\right.$, $p=0.005)$. WAY 100635 also significantly inhibited the effect of ASE on ACh efflux in the mPFC $\left(F_{1,9}=16.58\right.$, $P<0.001)$
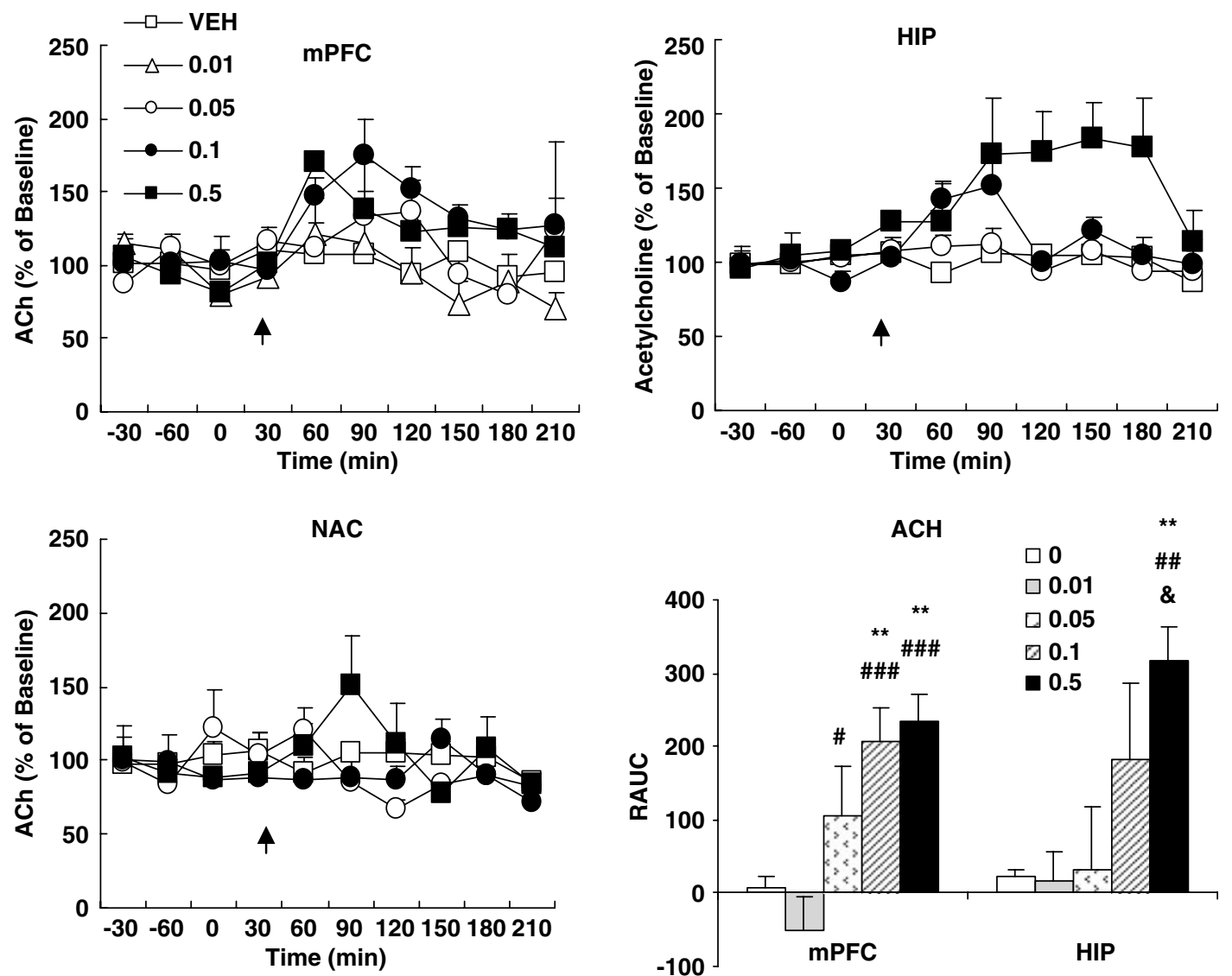

Figure 2 Effect of $\operatorname{ASE}(0.01,0.05,0.1$, and $0.5 \mathrm{mg} / \mathrm{kg}$, s.c.) on ACh efflux in the rat mPFC, HIP, and NAc. Data are means \pm SEM of the dialysate ACh levels, expressed as percentage of the baseline. The response AUC (RAUC) was significantly different among the treatment groups: $\mathrm{mPFC}$ ( $\mathrm{F}=7.02$ $p=0.00 \mathrm{I}), \operatorname{HIP}(F=3.99, p=0.02)$, but not the NAc. For the mPFC, post hoc analysis revealed that the vehicle group was significantly different from ASE $0.1 \mathrm{mg} / \mathrm{kg}(p=0.003)$ and ASE $0.5 \mathrm{mg} / \mathrm{kg}(p=0.002)$ groups. Also, ASE at $0.01 \mathrm{mg} / \mathrm{kg}$ was significantly different from ASE at $0.05 \mathrm{mg} / \mathrm{kg}(p=0.04)$, ASE at $0.1 \mathrm{mg} / \mathrm{kg}(p=0.00 \mathrm{I})$, and ASE at $0.5 \mathrm{mg} / \mathrm{kg}(p=0.00 \mathrm{I})$. For the HIP, ASE at $0.5 \mathrm{mg} / \mathrm{kg}$ was significantly different from the vehicle group $(p=0.004)$, and ASE at $0.5 \mathrm{mg} / \mathrm{kg}$ was different from ASE at $0.01 \mathrm{mg} / \mathrm{kg}(p=0.0 \mathrm{I})$ and ASE at $0.5 \mathrm{mg} / \mathrm{kg}(p=0.0 \mathrm{I})$. ${ }^{*}{ }^{*} p<0.0 \mathrm{I}$, vs vehicle; ${ }^{\#} p<0.05$, \#\# $p<0.0 \mathrm{I}$, and ${ }^{\# \# \#} p<0.00 \mathrm{I}$, vs ASE $0.01 \mathrm{mg} / \mathrm{kg}$ dose; and ${ }^{2} p<0.05$, vs ASE $0.05 \mathrm{mg} / \mathrm{kg}$ dose. VEH, vehicle. 

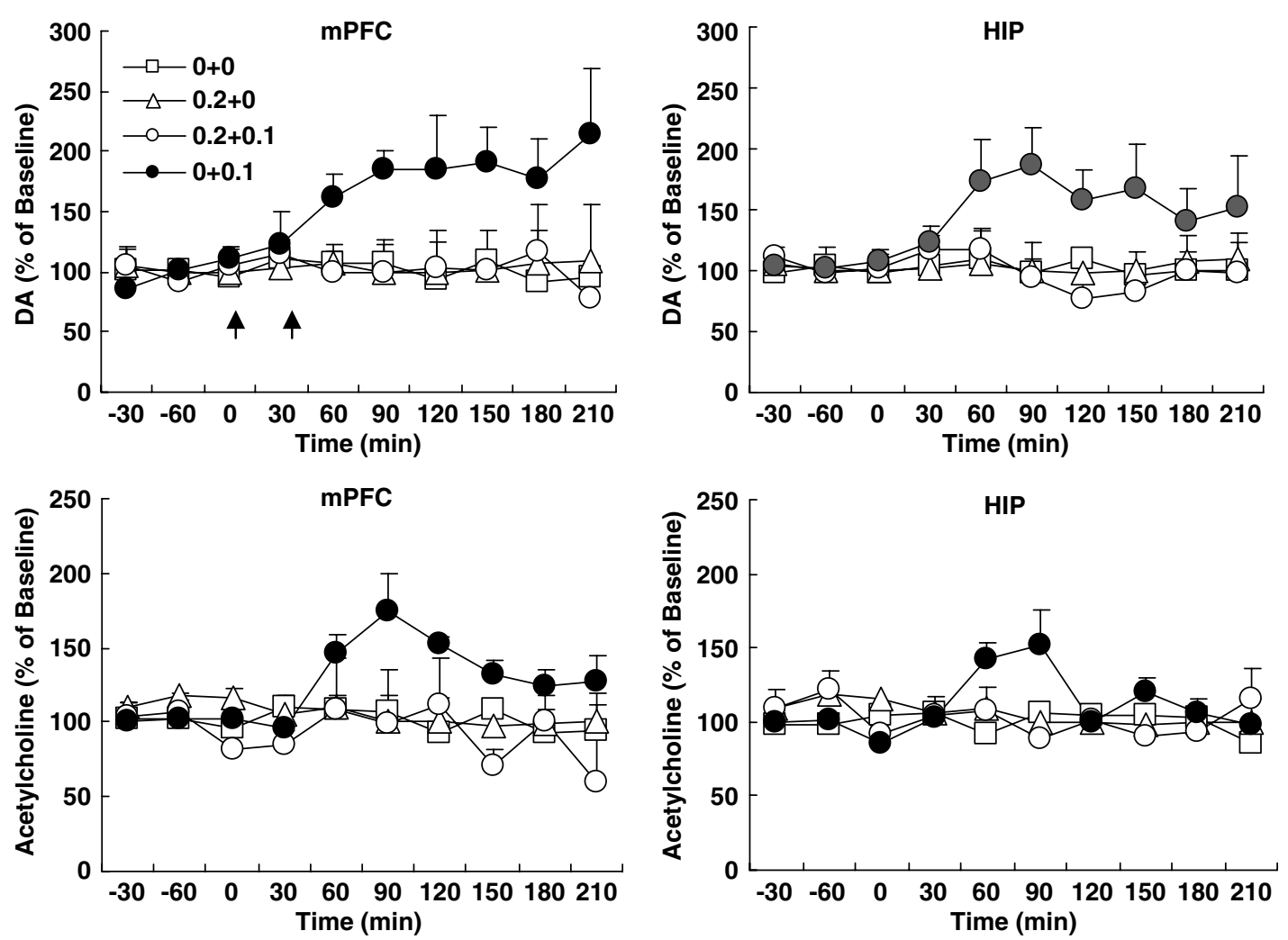

Figure 3 Effect of pretreatment with WAY 00635 (0.2 mg/kg, s.c.) on ASE (0.I mg/ $/ \mathrm{kg}, \mathrm{SC})$-induced DA and ACh efflux in rat mPFC and HIP. Data are means \pm SEM of the dialysate DA levels, expressed as percentage of the baseline. Pretreatment with WAY 00635 significantly blocked increased DA efflux induced by ASE at $0.1 \mathrm{mg} / \mathrm{kg}$ in both regions, and blocked ACh efflux in the mPFC. VEH, vehicle.

\section{Effect of ASE on NE Efflux in the mPFC and HIP}

ASE increased extracellular NE in the mPFC and HIP (Figure 4). Repeated-measure ANOVA of mPFC data showed significant overall group effect $(\mathrm{F}=5.08, p=0.01)$; the time effect was not significant. The group $\times$ time effect was not significant. Post hoc analysis of MPFC data revealed that ASE at $0.1 \mathrm{mg} / \mathrm{kg}$ was significantly different from the vehicle $(p=0.001)$, ASE at $0.01 \mathrm{mg} / \mathrm{kg}(p=0.01)$, and ASE at $0.05 \mathrm{mg} / \mathrm{kg}(p=0.01)$. For the HIP, both overall group $(\mathrm{F}=4.60, p=0.02)$ and time $(\mathrm{F}=2.40, p=0.03)$ effects were significant, but the group $\times$ time interaction was not. Post hoc analysis revealed that ASE at $0.1 \mathrm{mg} / \mathrm{kg}$ was significantly different from the vehicle $(p=0.01)$ and ASE at $0.01 \mathrm{mg} / \mathrm{kg}$ $(p=0.01)$. The response AUC (Figure 4) was significantly different among the treatment groups for each region, $\operatorname{mPFC}(\mathrm{F}=5.69, p=0.01)$ and HIP $(\mathrm{F}=4.45, p=0.02)$. Post hoc analysis results showed the same group differences within region as the repeated-measure ANOVA reported above. $P$-values for differences among the response AUCs are given in the legend to Figure 4.

Two-way ANOVA was used to compare the treatment group across the three regions. The interaction of region and treatment was not significant. The main effects of region, regardless of dose $(\mathrm{F}=3.20, p=0.05)$, and treatment group, regardless of region $(\mathrm{F}=15.35, p=0.0001)$, were significant. ASE at $0.05 \mathrm{mg} / \mathrm{kg}(p=0.03)$ and ASE at $0.1 \mathrm{mg} /$ $\mathrm{kg}(p=0.02)$, but not ASE at $0.5 \mathrm{mg} / \mathrm{kg}(p=0.09)$, produced greater increases on DA efflux in the mPFC compared with in the NAc; there were no differences between the effects of
ASE on DA efflux in the mPFC and HIP at any of the doses studied.

\section{Effect of ASE on Serotonin Efflux in the MPFC and HIP}

As shown in Figure 5, ASE, at 0.05 and $0.1 \mathrm{mg} / \mathrm{kg}$, had no effect on 5-HT efflux in either the mPFC or HIP.

\section{Effect of ASE on Glutamate and GABA Efflux in the MPFC and NAc}

ASE at $0.1 \mathrm{mg} / \mathrm{kg}$ had no significant effect on glutamate or GABA efflux in either the mPFC or NAc (data not shown).

\section{DISCUSSION}

The main findings of this study are the following: (1) ASE produced a dose-dependent increase in DA efflux in the mPFC and HIP; (2) ASE, at $0.5 \mathrm{mg} / \mathrm{kg}$, but not at lower doses increased DA efflux in the NAc; (3) ASE dose dependently increased ACh efflux in the MPFC and HIP, but not in the NAc; (4) the effect of ASE on DA efflux in the mPFC and HIP was blocked by pretreatment with the $5-\mathrm{HT}_{1 \mathrm{~A}}$ antagonist $/ \mathrm{D}_{4}$ agonist, WAY100635; (5) ASE increased NE efflux in the mPFC and HIP, but had no effect on 5-HT efflux in either region, at the doses tested; and (6) ASE, at the same dose that significantly increased DA and NE efflux in the MPFC and HIP, had no effect on glutamate and GABA efflux in the mPFC or NAc. These results suggest that acute 

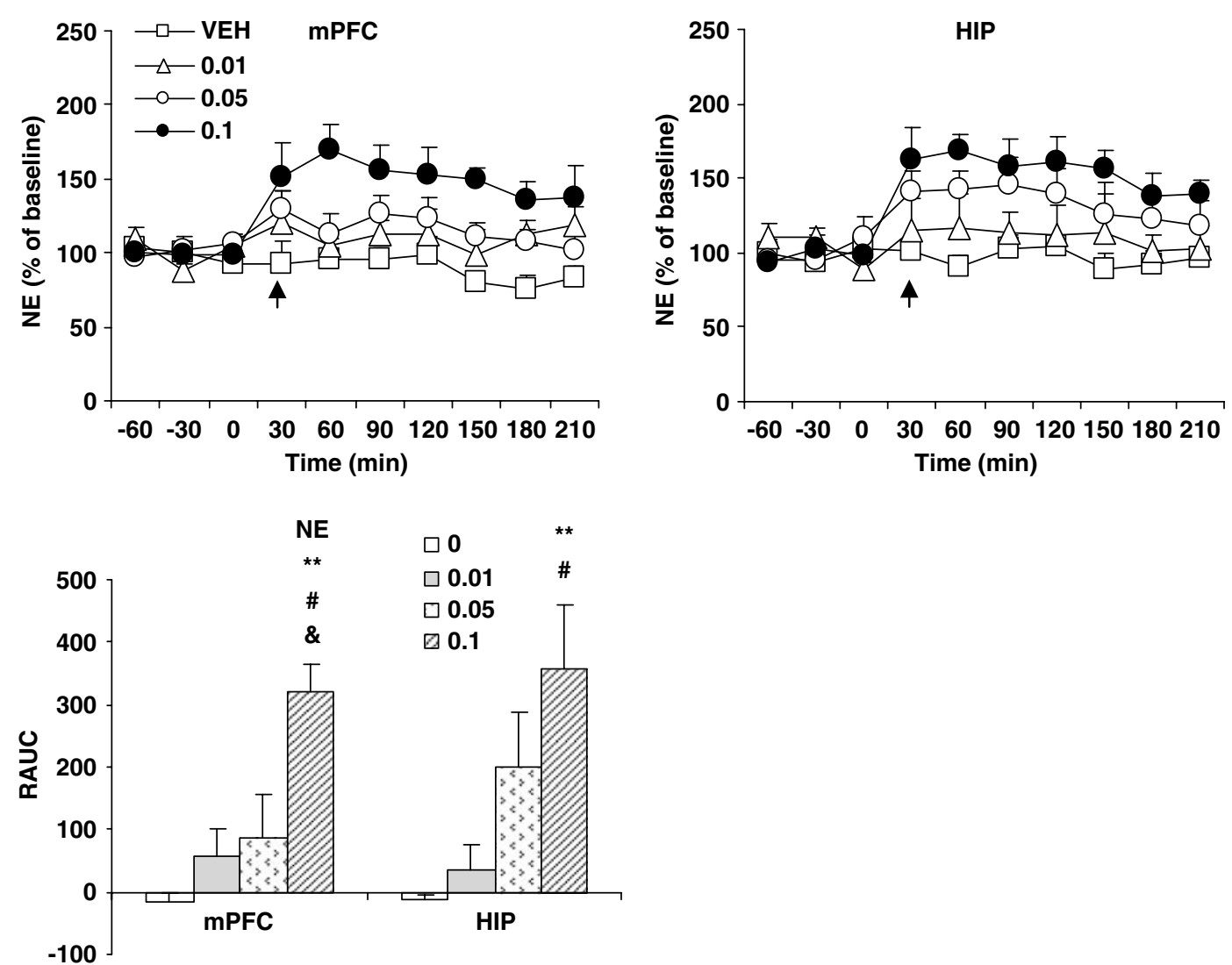

Figure 4 Effect of ASE (0.0I, 0.05, and $0.1 \mathrm{mg} / \mathrm{kg}$, s.c.) on NE efflux in the rat mPFC and HIP. Data are means \pm SEM of the dialysate NE levels, expressed as percentage of baseline. The response AUC (RAUC) was significantly different among the treatment groups for MPFC ( $F=5.69, p=0.0 \mathrm{I})$ and $\mathrm{HIP}$ $(F=4.45, p=0.02)$. For the mPFC, post hoc analysis revealed that the vehicle group was significantly different from the ASE $0.1 \mathrm{mg} / \mathrm{kg}(p=0.00 \mathrm{I})$ group. Also, ASE at $0.1 \mathrm{mg} / \mathrm{kg}$ was significantly different from ASE at $0.01 \mathrm{mg} / \mathrm{kg} 0.01 \mathrm{l}(p=0.0 \mathrm{I})$ and ASE at $0.05 \mathrm{mg} / \mathrm{kg}(p=0.0 \mathrm{I})$. For the HIP, the ASE $0.1 \mathrm{mg} / \mathrm{kg}$ group was significantly different from the vehicle group $(p=0.0 \mathrm{I})$. Also, ASE at $0.1 \mathrm{mg} / \mathrm{kg}$ was significantly different from ASE at $0.0 \mathrm{I} \mathrm{mg} / \mathrm{kg}(p=0.0 \mathrm{I})$. ${ }_{*}^{*} p<0.01$, vs vehicle; ${ }^{\#} p<0.05$, vs ASE $0.01 \mathrm{mg} / \mathrm{kg}$ dose; and ${ }^{\star} p<0.05$, vs ASE $0.05 \mathrm{mg} / \mathrm{kg}$ dose. VEH, vehicle.
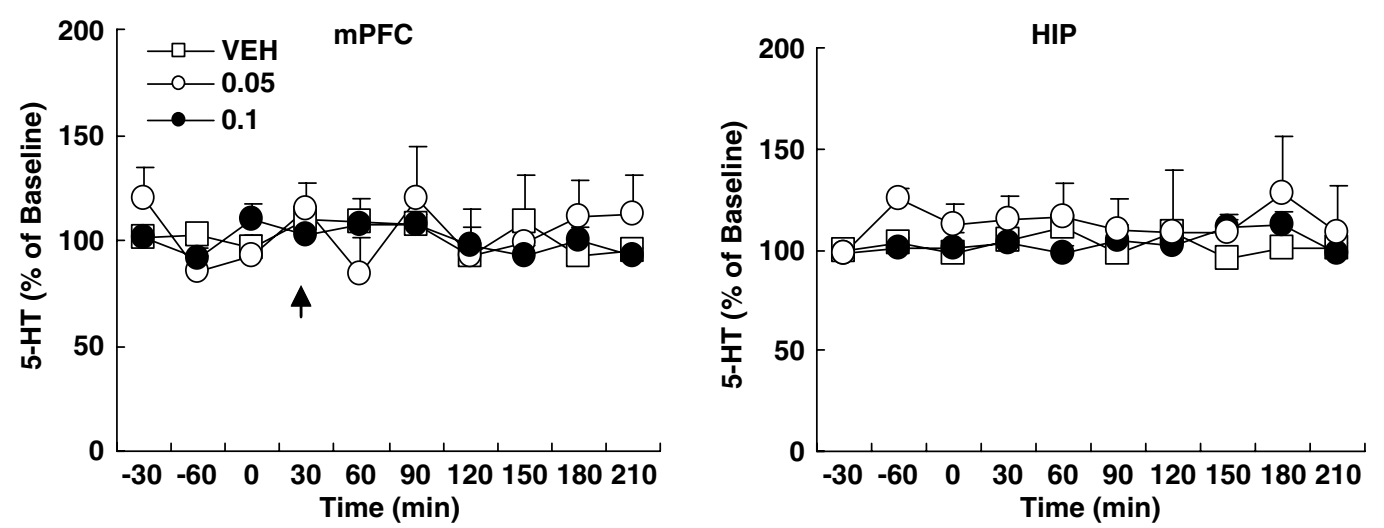

Figure 5 Effect of ASE (0.05 and $0.1 \mathrm{mg} / \mathrm{kg}$, s.c.) on serotonin $(5-\mathrm{HT})$ efflux in the rat mPFC and HIP. Data are means \pm SEM of the dialysate $5-\mathrm{HT}$ levels, expressed as percentage of baseline. ASE at 0.05 and $0.1 \mathrm{mg} / \mathrm{kg}$ had no effect on $5-\mathrm{HT}$ efflux in either region. VEH, vehicle.

treatment with ASE has effects on the MPFC, HIP, and NAc DA, NE, and ACh efflux comparable to those of clozapine and other atypical antipsychotic drugs, which are relatively more potent $5-\mathrm{HT}_{2 \mathrm{~A}}$ antagonists than $\mathrm{D}_{2}$ antagonists.

\section{DA Efflux}

Atypical antipsychotics have been reported to preferentially increase DA efflux in the MPFC and HIP compared with in the NAc in freely moving rats (Chung et al, 2004; Ichikawa et al, 2001; Kuroki et al, 1999), compared with typical antipsychotic drugs. ASE, in this study, at doses less than $0.5 \mathrm{mg} / \mathrm{kg}$, also showed preferential increase in cortical and HIP DA efflux compared with in the NAc. This action is due, in part, to blockade of $5-\mathrm{HT}_{2 \mathrm{~A}}$ receptors in the cerebral cortex and relatively weaker or negligible occupation of $\mathrm{D}_{2}$ and $D_{1}$ receptors (Matsubara et al, 1993), since it can be mimicked by the combination of potent $5-\mathrm{HT}_{2 \mathrm{~A}}$ antagonism 
and weak blockade of $\mathrm{D}_{2}$ receptors (Liegeois et al, 2002; Bonaccorso et al, 2002; Li et al, 2005). As reported by Schotte et al (1996), these agents, including clozapine, risperidone, 9-hydroxyrisperidone (paliperidone), olanzapine, pipamperone, quetiapine, sertindole, ziprasidone, and zotepine, also have higher occupancy in the rat cortex and striatum of 5- $\mathrm{HT}_{2 \mathrm{~A}}$ than $\mathrm{D}_{2}$ receptors, respectively, at all but the highest doses studied. PET studies are also consistent with the view that at clinically relevant doses, those agents, which are direct acting antagonists of $\mathrm{D}_{2}$ receptors, have higher occupancy of $\mathrm{D}_{2}$ than 5- $\mathrm{HT}_{2 \mathrm{~A}}$ receptors (Goyer et al, 1996; Nyberg et al, 1999; Gefvert et al, 2001; Kessler et al, 2005). Aripiprazole, a partial $D_{2}$ receptor agonist, has a higher $\mathrm{D}_{2}$ than $5-\mathrm{HT}_{2 \mathrm{~A}}$ receptor occupancy at clinical doses, but, nevertheless, has a weak functional effect to inhibit $\mathrm{D}_{2}$ receptor stimulation (Mamo et al, 2007). As mentioned under Introduction, diminished dopaminergic and noradrenergic function in the cortex and HIP have been implicated in the pathophysiology of cognitive impairment, negative symptoms, and perhaps depression in patients with schizophrenia (Meltzer and McGurk, 1999; Millan, 2006; Juckel et al, 2006). Recent studies have clearly demonstrated the importance of increased cortical $D_{1}$ receptor stimulation for specific types of memory, including working memory and social memory (Castner and Williams, 2007; Nagai et al, 2007), possibly by increasing the activity of pyramidal neurons, modulation of glutamate NMDA receptor signaling at critical nodes within local circuits and distributed networks (Castner and Williams, 2007), fine tuning GABAergic interneurons (Kroner et al, 2007), and enhancing the release of cortical ACh (Di Cara et al, 2007). Thus, these effects on the efflux of cortical DA and NE may be clinically relevant to the treatment of schizophrenia (Ichikawa et al, 2001; Meltzer et al, 2003; Arnsten and Li, 2005), as well as to the ability of these same agents, in combination with at least some antidepressant drugs, to be effective in patients with major depression who fail to respond to antidepressant drug treatment alone (Shelton et al, 2001).

The increased efflux of DA in the mPFC and HIP produced by antipsychotic drugs (eg, aripiprazole, clozapine, olanzapine, risperidone, ziprasidone) has been shown to be partially or completely (eg, quetiapine) blocked by the $5-\mathrm{HT}_{1 \mathrm{~A}}$ antagonist/ $\mathrm{D}_{4}$ receptor agonist WAY 100635 in most (Ago et al, 2005; Chung et al, 2004; Ichikawa et al, 2001; Ichikawa and Meltzer, 2000; Li et al, 2004; Sprouse et al, 1999; Yoshino et al, 2004), but not all (Assie et al, 2005), studies. Although the recent demonstration of relatively potent $\mathrm{D}_{4}$ agonist activity of WAY100635 (Chemel et al, 2006) complicates the interpretation of studies with this agent, the role of 5- $\mathrm{HT}_{1 \mathrm{~A}}$ receptor agonism in mediating the effects of atypical antipsychotics on mPFC DA efflux is also supported by experiments in which the highly selective $5-\mathrm{HT}_{1 \mathrm{~A}}$ agonist, $\mathrm{BAY} \times 3702 \quad$ (BAY; $10-40 \mu \mathrm{g} / \mathrm{kg}$, i.v.), increased DA release in the mPFC. WAY 100635 reversed the effects of BAY in both the areas. The atypical antipsychotics, clozapine, olanzapine, and ziprasidone (but not haloperidol), enhanced DA release in the mPFC of wild-type, but not $5-\mathrm{HT}_{1 \mathrm{~A}}$-knockout, mice after systemic and local (clozapine and olanzapine) administration in the mPFC (Diaz-Mataix et al, 2005). Local administration of WAY100635 into the mPFC of male rats blocks the effect of systemic clozapine on cortical DA release ( $\mathrm{Li}$ et al, unpublished data). ASE is similar to quetiapine (Ichikawa et al, 2002c) in that its ability to increase the efflux of cortical DA in rats was completely blocked by WAY 100635 . The clinical significance, if any, of this difference is unknown at present. The increase in cortical DA release produced by local injection of clozapine or olanzapine into the cortex was also abolished in $5-\mathrm{HT}_{1 \mathrm{~A}}$-knockout mice (Diaz-Mataix et al, 2005). Partial agonism at the 5-HT $1 \mathrm{~A}$ receptor has been reported for some (eg, clozapine, quetiapine, ziprasidone), but not all, atypical antipsychotic drugs (eg, olanzapine and risperidone) (Meltzer et al, 2003), a possible explanation for the blockade of the antipsychoticinduced DA efflux by WAY100635. Unlike clozapine, quetiapine, and ziprasidone (Meltzer et al, 2003), ASE does not behave like a $5-\mathrm{HT}_{1 \mathrm{~A}}$ agonist in cloned cell preparations (Shahid et al, 2007), nor does it enhance cortical 5-HT efflux at the doses tested. Thus, the mechanism by which ASE influences $5-\mathrm{HT}_{1 \mathrm{~A}}$-receptor stimulation requires further investigation.

ASE significantly increased DA efflux in the NAc at the highest dose studied $(0.5 \mathrm{mg} / \mathrm{kg})$, but not at $0.05 \mathrm{mg} / \mathrm{kg}$, which increased DA efflux in the MPFC and HIP. Atypical antipsychotic drugs, including clozapine and olanzapine, can increase DA efflux in the NAc, although the magnitude of the effect is significantly smaller than that produced in the mPFC (Ichikawa et al, 2002c; Kuroki et al, 1999; Shilliam and Dawson, 2005). Shilliam and Dawson (2005) demonstrated that this increase was confined to the shell of the NAc and did not occur in the NAc core. We have previously shown that $5-\mathrm{HT}_{2 \mathrm{C}}$-receptor antagonism, in combination with $\mathrm{D}_{2}$-receptor antagonism, may contribute to the ability of these agents to enhance DA release in the NAc (Bonaccorso et al, 2002; $\mathrm{Li}$ et al, 2005). The potent $5-\mathrm{HT}_{2 \mathrm{C}}$ antagonist, SB242084, significantly potentiated low-dose haloperidolinduced increase in DA release in the NAc (Li et al, 2005). The selective 5- $\mathrm{HT}_{2 \mathrm{C}}$ antagonists, SB206553 and SB242084, alone have been shown to increase DA efflux in both the mPFC and NAc (De Deurwaerdere and Spampinato, 2001; Di Matteo et al, 2001, 1998, 1999, 2000; Millan et al, 1998, 2003). As ASE is a very potent $5-\mathrm{HT}_{2 \mathrm{C}}$ antagonist $\left(\mathrm{p} K_{\mathrm{i}} 10.46 \pm 0.15\right.$; Shahid et al, 2007; Prinssen et al, 2000), this may, at least in part, be involved in mediating its effects in the NAc. Occupancy of $\mathrm{D}_{2}$ receptors may also contribute to the ability of ASE to enhance DA efflux in the NAc (Kuroki et al, 1999). There is also some evidence that the increase in DA efflux produced by the atypical antipsychotic drugs is mediated, in part, by $\alpha_{2 \mathrm{~A}}$-adrenergic-receptor blockade (Blake et al, 1998; Bymaster et al, 1996; Gobert et al, 1998; Hertel et al, 1999; Millan et al, 2000; Wadenberg et al, 2007), which may also contribute to the action of ASE in this regard, as it also an $\alpha_{2 \mathrm{~A}}$-adrenergic-receptor antagonist (Shahid et al, 2007).

\section{ACh Efflux}

ASE preferentially increased ACh efflux in both the mPFC and HIP, but not in the NAc, which is also the case for clozapine, olanzapine, risperidone, quetiapine, and ziprasidone (Ichikawa et al, 2002a, b, c; Parada et al, 1997; ShiraziSouthall et al, 2002). Muscarinic cholinergic receptors are unlikely to be important for this action, since, unlike 
clozapine or olanzapine, ASE has no appreciable affinity for these receptors (Shahid et al, 2007). Indirect $5-\mathrm{HT}_{1 \mathrm{~A}^{-}}$ receptor stimulation seems more likely to be important for this effect, since the increase in ACh induced by ASE is sensitive to blockade by WAY100635. This is similar to the profile of quetiapine (Ichikawa et al, 2002c). It has recently been reported that systemic administration of risperidone, at 1 and $2 \mathrm{mg} / \mathrm{kg}$, dose dependently increased ACh efflux in the rat $\mathrm{mPFC}$; this increase was antagonized by systemic administration of high ( 1 and $3 \mathrm{mg} / \mathrm{kg}$ ), but not by a lower dose $(0.1 \mathrm{mg} / \mathrm{kg})$ of WAY100635, which preferentially blocks presynaptic 5- $\mathrm{HT}_{1 \mathrm{~A}}$ autoreceptors (Sato et al, 2007; Ago et al, 2003). Local application of WAY100635 into the mPFC did not affect ACh release in the $\mathrm{MPFC}$, but did attenuate risperidone-induced increases in ACh efflux (Sato et al, 2007). Local application of neither risperidone (3 and $10 \mu \mathrm{M}$ ) and the 5-HT $1 \mathrm{~A}$-receptor agonist, L-750,667 (8-hydroxy-2-(di-n-propylamino)tetralin; 1 and $10 \mu \mathrm{M})$, nor the DA $\mathrm{D}_{4}$-receptor antagonist, 3-(4-(4-iodophenyl)piperazine-1-yl)methyl-1H-pyrrolo[2,3-b]pyridine (1 and $10 \mu \mathrm{M})$, into the mPFC affected ACh release in the MPFC (Sato et al, 2007). Taken together, these results suggest that atypical antipsychotic drugs increase ACh efflux in the mPFC through a circuit, which includes prefrontal 5- $\mathrm{HT}_{1 \mathrm{~A}}$-receptor activation. Histamine $\mathrm{H}_{1}$ and $\alpha_{2}$-adrenoceptor blockade have also been shown to enhance ACh release (Dringenberg et al, 1998; Tellez et al, 1997), and, thus, may be also involved in ASE-induced ACh release in both $\mathrm{MPFC}$ and HIP.

\section{NE and Serotonin Release}

ASE, like other atypical antipsychotics, dose dependently increased NE release in the rat MPFC and HIP (Westerink et al, 1998). ASE increased DA efflux in the mPFC at $0.05 \mathrm{mg} / \mathrm{kg}$, but not NE. The increases in DA and NE efflux in the $\mathrm{mPFC}$ at $0.1 \mathrm{mg} / \mathrm{kg}$ were comparable. The effect on DA and NE efflux in the HIP were more similar. Increased NE efflux, rather than, or in addition to, DA efflux, may be important for the ability of atypical antipsychotic drugs to improve cognitive function in schizophrenia (Arnsten and $\mathrm{Li}, 2005$; Rossetti and Carboni, 2005). Increases in NE and $\mathrm{DA}$ release in the rat $\mathrm{MPFC}$ have been reported with 5-HT ${ }_{1 \mathrm{~A}}$-receptor agonists (Hajos-Korcsok et al, 1999; Owen and Whitton, 2003); the $\alpha_{2}$-adrenoceptor antagonists RS79948 (Devoto et al, 2004) and 1-(2-pyrimidinyl-piperazine) (Gobert et al, 1999); and the selective $5-\mathrm{HT}_{2 \mathrm{C}}$ antagonist, SB242084 (Millan et al, 1998). As previously noted, ASE is a potent $5-\mathrm{HT}_{2 \mathrm{C}}$-receptor and $\alpha_{2}$-adrenoceptor antagonist (Schotte et al, 1996; Shahid et al, 2007). A combination of these actions may mediate its ability to increase NE and DA efflux in the MPFC and HIP.

ASE did not affect 5-HT efflux in either the MPFC or HIP at the doses tested, despite its $\alpha_{2}$-adrenoceptor-antagonist properties. The $\alpha_{2}$-adrenoceptor antagonist, yohimbine, increased, and the $\alpha_{2}$-agonist, clonidine, decreased, the extracellular levels of 5-HT in the rat frontal cortex (Cheng et al, 1993). One possible explanation for the lack of effect of ASE on 5-HT efflux is that the degree of $\alpha_{2}$-adrenoceptor block was insufficient at the doses used in the current study, but this seems unlikely in that it its affinity for the $\alpha_{2}$ adrenoceptoris identical to that for the $D_{2,1}$ receptor. Alternatively, given the complex multireceptor profile of atypical antipsychotic drugs, the inability of ASE to elevate cortical 5-HT levels may results from action, which negates the effects of $\alpha_{2}$-adrenoceptor blockade. Indeed, risperidone has been reported in several studies to increase mPFC 5-HT release (Cartmell et al, 2001; Hertel et al, 1996; Ichikawa et al, 1998), whereas clozapine and olanzapine do not. The lack of an increase in 5-HT efflux in the mPFC by ASE suggests that stimulation of $5-\mathrm{HT}_{1 \mathrm{~A}}$ receptors, which appears to be critical for its ability to enhance ACh and DA efflux, is not due to 5-HT efflux in this region. This is consistent with the evidence that local administration of the 5- $\mathrm{HT}_{1 \mathrm{~A}}$ agonist, 8-OH-DPAT, did not enhance ACh efflux in the mPFC (Sato et al, 2007).

\section{Glutamate and GABA Efflux}

In the present study, ASE did not alter extracellular glutamate and GABA levels in the mPFC, at a dose that did enhance DA, $\mathrm{NE}$, and ACh efflux in that region. It also had no effect on glutamate or GABA efflux in the NAc. In this regard, it differs from clozapine, which significantly increased glutamate efflux in the rat mPFC (Daly and Moghaddam, 1993; Yamamoto and Cooperman, 1994). It also differs from clozapine and haloperidol, which decreased basal GABA release in the mPFC (Bourdelais and Deutch, 1994). These data indicate that modulation of cortical glutamate and GABA efflux does not represent a common action of antipsychotic drugs. The significance of these differences between antipsychotic drugs remains to be determined.

Both risperidone and clozapine have been reported to diminish GABA release in the globus pallidus (Grimm and See, 1998). Clozapine has also been shown to dose dependently block phencyclidine-induced acute increases in glutamate efflux in the rat mPFC, as well as to block PCPinduced hyperlocomotion. Clozapine also attenuated acute increases in glutamate efflux in the $\mathrm{mPFC}$ induced by local perfusion with the competitive NMDA-receptor antagonist, CPP (Abekawa et al, 2006). Further study of a broader dose range of ASE is required to assess the effects of ASE on glutamatergic mechanisms.

\section{Conclusions}

In conclusion, acute administration of ASE significantly increased cortical and hippocampal DA, NE, and ACh efflux in a dose-dependent and regionally selective manner, but had no effect on cortical and HIP 5-HT, glutamate, or GABA efflux. The effects on DA, NE, and ACh efflux are comparable to those previously reported with clozapine and quetiapine. Several key differences between clozapine and ASE were noted, including the ability of WAY100635 to block ACh efflux and the lack of an effect on cortical GABA and glutamate efflux. Overall, these results suggest ASE is an antipsychotic, which should improve cognition and negative symptoms in schizophrenia. Further study of its efficacy and side effect profile is clearly of interest.

\section{ACKNOWLEDGEMENTS}

This work was supported, in part, by an investigatorinitiated grant from Organon Laboratories Limited to HYM and by Pfizer Inc. 


\section{DISCLOSURE/CONFLICT OF INTEREST}

HYM has been a consultant to, or a grantee, or both, of the following pharmaceutical companies within the past 3 years: Abbott, ACADIA, ARYx, Astra Zeneca, BioLine Rx, Bristol Meyers Squibb, Cephalon, Eli Lilly, GSK, Janssen Pharmaceuticals, Minster, Organon Laboratories Limited, Ovation, Pfizer, SK, Solvay and Takeda. Mohammed Shahid is an employee and shareholder of Organon Laboratories Limited. Erik Wong was an employee of Pfizer Inc. during the period of his work on this research, and is a shareholder of Pfizer. Erik Wong is currently an employee of Astra Zeneca. The author(s) declare that, except for income received from their primary employers, no financial support or compensation has been received from any individual or corporate entity over the past 3 years for research or professional services, and they have no personal financial holdings that could be perceived as constituting a potential conflict of interest, with the exception that HYM is a stockholder of ACADIA, which has no direct or indirect involvement in this study.

\section{REFERENCES}

Abekawa T, Ito K, Koyama T (2006). Role of the simultaneous enhancement of NMDA and dopamine D1 receptor-mediated neurotransmission in the effects of clozapine on phencyclidineinduced acute increases in glutamate levels in the rat medial prefrontal cortex. Arch Pharmacol 374: 177-193.

Ago Y, Koyama Y, Baba A, Matsuda T (2003). Regulation by 5$\mathrm{HT}_{1 \mathrm{~A}}$ receptors of the in vivo release of 5-HT and DA in mouse frontal cortex. Neuropharmacology 45: 1050-1056.

Ago Y, Nakamura S, Baba A, Matsuda T (2005). Sulpiride in combination with fluvoxamine increases in vivo dopamine release selectively in rat prefrontal cortex. Neuropsychopharmacology 30: 43-51.

Alphs L, Panagides J, Lancaster S (2007). Asenapine in the treatment of negative symptoms of schizophrenia: clinical trial design and rationale. Psychopharmacol Bull 40: 41-53.

Arnsten AF, Li BM (2005). Neurobiology of executive functions: catecholamine influences on prefrontal cortical functions. Biol Psychiatry 57: 1377-1384.

Assie MB, Ravailhe V, Faucillon V, Newman-Tancredi A (2005). Contrasting contribution of 5-hydroxytryptamine $1 \mathrm{~A}$ receptor activation to neurochemical profile of novel antipsychotics: frontocortical dopamine and hippocampal serotonin release in rat brain. J Pharmacol Exp Thera 315: 265-272.

Benes FM, Berretta S (2000). Amygdalo-entorhinal inputs to the hippocampal formation in relation to schizophrenia. Ann NY Acad Sci 911: 293-304.

Blake TJ, Tillery CE, Reynolds GP (1998). Antipsychotic drug affinities at alpha2-adrenoceptor subtypes in post-mortem human brain. J Psychopharmacology 12: 151-154.

Bonaccorso S, Meltzer HY, Li Z, Dai J, Alboszta AR, Ichikawa J (2002). SR46349-B, a 5-HT(2A/2C) receptor antagonist, potentiates haloperidol-induced dopamine release in rat medial prefrontal cortex and nucleus accumbens. Neuropsychopharmacology 27: 430-441.

Bourdelais AJ, Deutch AY (1994). The effects of haloperidol and clozapine on extracellular GABA levels in the prefrontal cortex of the rat: an in vivo microdialysis study. Cereb Cortex 4: 69-77.

Broekkamp CL, De Graaf JS, van Delft AM (1990). Behavioural pharmacology of trans-5-chloro-2-methyl-2,3,3a,12b-tetrahydro1H-dibenz[2,3:6,7]oxepino-[4,5-c]pyrrolidine maleate, a compound interacting with dopaminergic and serotonergic receptors. Arzneimittelforschung 40: 544-549.
Bymaster FP, Calligaro DO, Falcone JF, Marsh RD, Moore NA, Tye NC et al (1996). Radioreceptor binding profile of the atypical antipsychotic olanzapine. Neuropsychopharmacology 14: 87-96.

Bymaster FP, Felder C, Ahmed S, McKinzie D (2002). Muscarinic receptors as a target for drugs treating schizophrenia. Current Drug Targets CNS Neurol Disord 1: 163-181.

Cartmell J, Perry KW, Salhoff CR, Monn JA, Schoepp DD (2001). Acute increases in monoamine release in the rat prefrontal cortex by the mGlu2/3 agonist LY379268 are similar in profile to risperidone, not locally mediated, and can be elicited in the presence of uptake blockade. Neuropharmacology 40: 847-855.

Castner SA, Williams GV (2007). Tuning the engine of cognition: a focus on NMDA/D1 receptor interactions in prefrontal cortex. Brain Cogn 63: 94-122.

Chemel BR, Roth BL, Armbruster B, Watts VJ, Nichols DE (2006). WAY-100635 is a potent dopamine D4 receptor agonist. Psychopharmacology (Berl) 188: 244-251.

Cheng CH, Costall B, Ge J, Naylor RJ (1993). The profiles of interaction of yohimbine with anxiolytic and putative anxiolytic agents to modify 5-HT release in the frontal cortex of freelymoving rats. $\mathrm{Br} J$ Pharmacol 110: 1079-1084.

Chung YC, Li Z, Dai J, Meltzer HY, Ichikawa J (2004). Clozapine increases both acetylcholine and dopamine release in rat ventral hippocampus: role of 5-HT1A receptor agonism. Brain Res 1023: 54-63.

Cosi C, Koek W (2001). Agonist, antagonist, and inverse agonist properties of antipsychotics at human recombinant 5-HT(1A) receptors expressed in HeLa cells. Eur J Pharmacol 433: 55-62.

Costall B, Domeney AM, Kelly ME, Naylor RJ, Tomkins DM (1990). Actions of ORG 5222 as a novel psychotropic agent. Pharmacol Biochem Behav 35: 607-615.

Coyle JT (2006). Glutamate and schizophrenia: beyond the dopamine hypothesis. Cell Mol Neurobiol 26: 365-384.

Daly DA, Moghaddam B (1993). Actions of clozapine and haloperidol on the extracellular levels of excitatory amino acids in the prefrontal cortex and striatum of conscious rats. Neurosci Lett 152: 61-64.

De Boer T, Berendsen H, Broekkamp CLE, Vrjimoed-de Vriès MC, Vos RME, Tonnaer JA et al (1993). Org-5222. Drugs Future 18: 1117-1123.

De Boer T, Tonnaer JA, De Vos CJ, Van Delft AM (1990). Neurochemical studies with the potential antipsychotic compound trans-5-chloro-2-methyl-2,3,3a,12b-tetrahydro-1Hdibenz[2,3:6,7]oxepino[4,5-c]pyrrolidine maleate. Arzneimittelforschung 40: $550-554$.

De Deurwaerdere P, Spampinato U (2001). The nigrostriatal dopamine system: a neglected target for 5-HT2C receptors. Trends Pharmacol Sci 22: 502-504.

Devoto P, Flore G, Pira L, Longu G, Gessa GL (2004). Alpha2adrenoceptor mediated co-release of dopamine and noradrenaline from noradrenergic neurons in the cerebral cortex. J Neurochem 88: 1003-1009.

Di Cara B, Panayi F, Gobert A, Dekeyne A, Sicard D, De Groote L et al (2007). Activation of dopamine D1 receptors enhances cholinergic transmission and social cognition: a parallel dialysis and behavioural study in rats. Int J Neuropsychopharmacol 10: 383-399.

Di Matteo V, De Blasi A, Di Giulio C, Esposito E (2001). Role of 5 -HT(2C) receptors in the control of central dopamine function. Trends Pharmacol Sci 22: 229-232.

Di Matteo V, Di Giovanni G, Di Mascio M, Esposito E (1998). Selective blockade of serotonin2C/2B receptors enhances dopamine release in the rat nucleus accumbens. Neuropharmacology 37: 265-272.

Di Matteo V, Di Giovanni G, Di Mascio M, Esposito E (1999). SB 242084, a selective serotonin2C receptor antagonist, increases dopaminergic transmission in the mesolimbic system. Neuropharmacology 38: 1195-1205. 
Di Matteo V, Di Mascio M, Di Giovanni G, Esposito E (2000). Acute administration of amitriptyline and mianserin increases dopamine release in the rat nucleus accumbens: possible involvement of serotonin2C receptors. Psychopharmacology (Berl) 150: 45-51.

Diaz-Mataix L, Scorza MC, Bortolozzi A, Toth M, Celada P, Artigas F (2005). Involvement of 5-HT1A receptors in prefrontal cortex in the modulation of dopaminergic activity: role in atypical antipsychotic action. J Neurosci 25: 10831-10843.

Dringenberg HC, De Souza-Silva MA, Rossmuller J, Huston JP, Schwarting RK (1998). Histamine H1 receptor antagonists produce increases in extracellular acetylcholine in rat frontal cortex and hippocampus. J Neurochem 70: 1750-1758.

Gefvert O, Lundberg T, Wieselgren IM, Bergstrom M, Langstrom $\mathrm{B}$, Wiesel $\mathrm{F}$ et al (2001). D(2) and 5HT(2A) receptor occupancy of different doses of quetiapine in schizophrenia: a PET study. Eur Neuropsychopharmacol 11: 105-110.

Gobert A, Rivet JM, Audinot V, Newman-Tancredi A, Cistarelli L, Millan MJ (1998). Simultaneous quantification of serotonin, dopamine and noradrenaline levels in single frontal cortex dialysates of freely-moving rats reveals a complex pattern of reciprocal auto- and heteroreceptor-mediated control of release. Neuroscience 84: 413-429.

Gobert A, Rivet JM, Cistarelli L, Melon C, Millan MJ (1999). Buspirone modulates basal and fluoxetine-stimulated dialysate levels of dopamine, noradrenaline and serotonin in the frontal cortex of freely moving rats: activation of serotonin $1 \mathrm{~A}$ receptors and blockade of alpha2-adrenergic receptors underlie its actions. Neuroscience 93: 1251-1262.

Goyer PF, Berridge MS, Morris ED, Semple WE, Compton-Toth BA, Schulz SC et al (1996). PET measurement of neuroreceptor occupancy by typical and atypical neuroleptics. J Nucl Med 37: $1122-1127$.

Grimm JW, See RE (1998). Unique activation of extracellular striato-pallidal neurotransmitters in rats following acute risperidone. Brain Res 801: 182-189.

Hajos-Korcsok E, McQuade R, Sharp T (1999). Influence of 5HT1A receptors on central noradrenergic activity: microdialysis studies using (+/-)-MDL 73005EF and its enantiomers. Neuropharmacology 38: 299-306.

Harvey PD, Keefe RS (2001). Studies of cognitive change in patients with schizophrenia following novel antipsychotic treatment. Am J Psychiatry 158: 176-184.

Heidbreder CA, Foxton R, Cilia J, Hughes ZA, Shah AJ, Atkins A et al (2001). Increased responsiveness of dopamine to atypical, but not typical antipsychotics in the medial prefrontal cortex of rats reared in isolation. Psychopharmacology (Berl) 156: 338-351.

Hertel P, Fagerquist MV, Svensson TH (1999). Enhanced cortical dopamine output and antipsychotic-like effects of raclopride by alpha2 adrenoceptor blockade. Science 286: 105-107.

Hertel P, Nomikos GG, Iurlo M, Svensson TH (1996). Risperidone: regional effects in vivo on release and metabolism of dopamine and serotonin in the rat brain. Psychopharmacology (Berl) 124: 74-86.

Hirsch SR, Das I, Garey LJ, de Belleroche J (1997). A pivotal role for glutamate in the pathogenesis of schizophrenia, and its cognitive dysfunction. Pharmacol Biochem Behav 56: 797-802.

Ichikawa J, Dai J, Meltzer HY (2002a). 5-HT(1A) and 5-HT(2A) receptors minimally contribute to clozapine-induced acetylcholine release in rat medial prefrontal cortex. Brain Res 939: 34-42.

Ichikawa J, Dai J, O’Laughlin IA, Fowler WL, Meltzer HY (2002b). Atypical, but not typical, antipsychotic drugs increase cortical acetylcholine release without an effect in the nucleus accumbens or striatum. Neuropsychopharmacology 26: 325-339.

Ichikawa J, Ishii $\mathrm{H}$, Bonaccorso S, Fowler WL, O'Lauqhlin IA, Meltzer HY (2001). 5-HT(2A) and $\mathrm{D}(2)$ receptor blockade increases cortical DA release via 5-HT(1A) receptor activation: a possible mechanism of atypical antipsychotic-induced cortical dopamine release. J Neurochem 76: 1521-1531.

Ichikawa J, Kuroki T, Dai J, Meltzer HY (1998). Effect of antipsychotic drugs on extracellular serotonin levels in rat medial prefrontal cortex and nucleus accumbens. Eur $J$ Pharmacol 351: 163-171.

Ichikawa J, Li Z, Dai J, Meltzer HY (2002c). Atypical antipsychotic drugs, quetiapine, iloperidone, and melperone, preferentially increase dopamine and acetylcholine release in rat medial prefrontal cortex: role of 5-HT1A receptor agonism. Brain Res 956: 349-357.

Ichikawa J, Meltzer HY (2000). The effect of $\operatorname{serotonin}(1 \mathrm{~A})$ receptor agonism on antipsychotic drug-induced dopamine release in rat striatum and nucleus accumbens. Brain Res 858: 252-263.

Juckel G, Schlagenhauf F, Koslowski M, Wustenberg T, Villringer A, Knutson B et al (2006). Dysfunction of ventral striatal reward prediction in schizophrenia. Neuroimage 29: 409-416.

Keefe RS, Bilder RM, Davis SM, Harvey PD, Palmer BW, Gold JM et al (2007). CATIE Investigators. Neurocognitive Working Group. Neurocognitive effects of antipsychotic medications in patients with chronic schizophrenia in the CATIE Trial. Arch Gen Psychiatry 64: 633-647.

Kessler RM, Ansari MS, Riccardi P, Li R, Jayathilake K, Dawant B et al (2005). Occupancy of striatal and extrastriatal dopamine D2/D3 receptors by olanzapine and haloperidol. Neuropsychopharmacology 30: 2283-2289.

Konradi C, Heckers S (2003). Molecular aspects of glutamate dysregulation: implications for schizophrenia and its treatment. Pharmacol Ther 97: 153-179.

Kroner S, Krimer LS, Lewis DA, Barrionuevo G (2007). Dopamine increases inhibition in the monkey dorsolateral prefrontal cortex through cell type-specific modulation of interneurons. Cerebral Cortex 17: 1020-1032.

Kuroki T, Meltzer HY, Ichikawa J (1999). Effects of antipsychotic drugs on extracellular dopamine levels in rat medial prefrontal cortex and nucleus accumbens. J Pharmacol Exp Ther 288: 774-781.

Li Z, Ichikawa J, Dai J, Meltzer HY (2004). Aripiprazole, a novel antipsychotic drug, preferentially increases dopamine release in the prefrontal cortex and hippocampus in rat brain. Eur $J$ Pharmacol 493: 75-83.

Li Z, Ichikawa J, Huang M, Dai J, Meltzer HY (2005). ACP-103, a 5-HT2A/2C inverse agonist, potentiates haloperidol-induced dopamine release in rat medial prefrontal cortex and nucleus accumbens. Psychopharmacology (Berl) 183: 144-153.

Liegeois JF, Ichikawa J, Meltzer HY (2002). 5-HT(2A) receptor antagonism potentiates haloperidol-induced dopamine release in rat medial prefrontal cortex and inhibits that in the nucleus accumbens in a dose-dependent manner. Brain Res 947: 157-165.

Mamo D, Graff A, Mizrahi R, Shammi CM, Romeyer F, Kapur S (2007). Differential effects of aripiprazole on D(2), 5-HT(2), and 5-HT(1A) receptor occupancy in patients with schizophrenia: a triple tracer PET study. Am J Psychiatry 164: 1411-1417.

Matsubara S, Matsubara R, Kusumi I, Koyama T, Yamashita I (1993). Dopamine D1, D2 and serotonin2 receptor occupation by typical and atypical antipsychotic drugs in vivo.J Pharmacol Exp Ther 265: 498-508.

Meltzer HY, Bobo WV, Roy A, Jayathilake K, Chen Y, Anil EA et al. (2008). A randomized, double-blind comparison of clozapine and high-dose treatment-resistant patients with schizophrenia. J Clin Psychiatry 69: 274-285.

Meltzer HY, Li Z, Kaneda Y, Ichikawa J (2003). Serotonin receptors: their key role in drugs to treat schizophrenia. Prog Neuropsychopharmacol Biol Psychiatry 27: 1159-1172.

Meltzer HY, Matsubara S, Lee JC (1989). Classification of typical and atypical antipsychotic drugs on the basis of dopamine D-1, D-2 and serotonin $2 \mathrm{p} K_{\mathrm{i}}$ values. J Pharmacol Exp Thera 251: 238-246. 
Meltzer HY, McGurk SR (1999). The effect of clozapine, risperidone and olanzapine on cognitive function in schizophrenia. Schizophr Bull 25: 233-255.

Millan MJ (2006). Multi-target strategies for the improved treatment of depressive states: conceptual foundations and neuronal substrates, drug discovery and therapeutic application. Pharmacol Ther 110: 135-370.

Millan MJ, Dekeyne A, Gobert A (1998). Serotonin (5-HT)2C receptors tonically inhibit dopamine (DA) and noradrenaline (NA), but not 5-HT, release in the frontal cortex in vivo. Neuropharmacology 37: 953-955.

Millan MJ, Gobert A, Lejeune F, Dekeyne A, Newman-Tancredi A, Pasteau $\mathrm{V}$ et al (2003). The novel melatonin agonist agomelatine (S20098) is an antagonist at 5-hydroxytryptamine2C receptors, blockade of which enhances the activity of frontocortical dopaminergic and adrenergic pathways. J Pharmacol Exp Ther 306: $954-964$.

Millan MJ, Gobert A, Rivet JM, Adhumeau-Auclair A, Cussac D, Newman-Tancredi A et al (2000). Mirtazapine enhances frontocortical dopaminergic and corticolimbic adrenergic, but not serotonergic, transmission by blockade of alpha2-adrenergic and serotonin2C receptors: a comparison with citalopram. Eur J Neurosci 12: 1079-1095.

Nagai T, Takuma K, Kamei H, Ito Y, Nakamichi N, Ibi D et al (2007). Dopamine D1 receptors regulate protein synthesisdependent long-term recognition memory via extracellular signal-regulated kinase $1 / 2$ in the prefrontal cortex. Learn Mem 14: 117-125.

Nakamura M, McCarley RW, Kubicki M, Dickey CC, Niznikiewicz MA, Voglmaier MM et al (2005). Fronto-temporal disconnectivity in schizotypal personality disorder: a diffusion tensor imaging study. Biol Psychiatry 58: 468-478.

Nyberg S, Eriksson B, Oxenstierna G, Halldin C, Farde L (1999). Suggested minimal effective dose of risperidone based on PETmeasured D2 and 5-HT2A receptor occupancy in schizophrenic patients. Am J Psychiatry 156: 869-875.

Owen JC, Whitton PS (2003). Reboxetine modulates norepinephrine efflux in the frontal cortex of the freely moving rat: the involvement of alpha 2 and 5-HT1A receptors. Neurosci Lett 348: 171-174.

Pantelis C, Barnes TR, Nelson HE, Tanner S, Weatherley L, Owen AM et al (1997). Frontal-striatal cognitive deficits in patients with chronic schizophrenia. Brain 120: 1823-1843.

Parada MA, Hernandez L, Puig de Parada M, Rada P, Murzi E (1997). Selective action of acute systemic clozapine on acetylcholine release in the rat prefrontal cortex by reference to the nucleus accumbens and striatum. J Pharmacol Exp Ther 281: 582-588.

Paxinos G, Watson C (1986). The Rat Brain in Stereotaxic Coordinates. Academic Press: New York, NY.

Potkin SG, Cohen M, Panagides J (2007). Efficacy and tolerability of asenapine in acute schizophrenia: a placebo- and risperidonecontrolled trial. J Clin Psychiatry 68: 1492-1500.

Prinssen EP, Koek W, Kleven MS (2000). The effects of antipsychotics with 5-HT(2C) receptor affinity in behavioral assays selective for $5-\mathrm{HT}(2 \mathrm{C})$ receptor antagonist properties of compounds. Eur J Pharmacol 388: 57-67.

Richelson E, Souder T (2000). Binding of antipsychotic drugs to human brain receptors focus on newer generation compounds. Life Sci 68: 29-39.

Rossetti ZL, Carboni S (2005). Noradrenaline and dopamine elevations in the rat prefrontal cortex in spatial working memory. J Neuroscience 25: 2322-2329.

Sato M, Ago Y, Koda K, Nakamura S, Kawasaki T, Baba A et al (2007). Role of postsynaptic serotonin1A receptors in risper- idone-induced increase in acetylcholine release in rat prefrontal cortex. Eur J Pharmacol 559: 155-160.

Schotte A, Janssen PF, Gommeren W, Luyten WH, Van Gompel P, Lesage AS et al (1996). Risperidone compared with new and reference antipsychotic drugs: in vitro and in vivo receptor binding. Psychopharmacology (Berl) 124: 57-73.

Selemon LD, Goldman-Rakic PS (1999). The reduced neuropil hypothesis: a circuit based model of schizophrenia. Biol Psychiatry 45: 17-25.

Shahid M, Walker GB, Zorn SH, Wong EHF (2007). Asenapine: a novel psychopharmacologic agent with a unique human receptor signature. J Psychopharmacol [e-pub ahead of print: 28 February 2008].

Shelton RC, Tollefson GD, Tohen M, Stahl S, Gannon KS, Jacobs TG et al (2001). A novel augmentation strategy for treating resistant major depression. Am J Psychiatry 158: 131-134.

Shilliam CS, Dawson LA (2005). The effect of clozapine on extracellular dopamine levels in the shell subregion of the rat nucleus accumbens is reversed following chronic administration: comparison with a selective 5-HT(2C) receptor antagonist. Neuropsychopharmacology 30: 372-380.

Shirazi-Southall S, Rodriguez DE, Nomikos GG (2002). Effects of typical and atypical antipsychotics and receptor selective compounds on acetylcholine efflux in the hippocampus of the rat. Neuropsychopharmacology 26: 583-594.

Sprouse JS, Reynolds LS, Braselton JP, Rollema H, Zorn SH (1999). Comparison of the novel antipsychotic ziprasidone with clozapine and olanzapine: inhibition of dorsal raphe cell firing and the role of 5-HT1A receptor activation. Neuropsychopharmacology 21: 622-631.

Tellez S, Colpaert F, Marien M (1997). Acetylcholine release in the rat prefrontal cortex in vivo: modulation by alpha 2-adrenoceptor agonists and antagonists. J Neurochem 68: 778-785.

Wadenberg ML, Wiker C, Svensson TH (2007). Enhanced efficacy of both typical and atypical antipsychotic drugs by adjunctive alpha 2 adrenoceptor blockade: experimental evidence. Int $\mathrm{J}$ Neuropsychopharmacol 10: 191-202.

Weinberger DR, Berman KF, Chase TN (1988). Mesocortical dopaminergic function and human cognition. Ann NY Acad Sci 537: 330-338.

Westerink BH, de Boer P, de Vries JB, Kruse CG, Long SK (1998). Antipsychotic drugs induce similar effects on the release of dopamine and noradrenaline in the medial prefrontal cortex of the rat brain. Eur J Pharmacol 361: 27-33.

Woodward ND, Purdon SE, Meltzer HY, Zald DH (2005). A metaanalysis of neuropsychological change to clozapine, olanzapine, quetiapine, and risperidone in schizophrenia. Int J Neuropsychopharmacol 8: 457-472.

Yamamoto BK, Cooperman MA (1994). Differential effects of chronic antipsychotic drug treatment on extracellular glutamate and dopamine concentrations. J Neurosci 14: 4159-4166.

Yamamoto BK, Pehek EA, Meltzer HY (1994). Brain region effects of clozapine on amino acid and monoamine transmission. J Clin Psychiatry 55(Suppl B): 8-14.

Yoshino T, Nisijima K, Shioda K, Yui K, Katoh S (2004). Perospirone, a novel atypical antipsychotic drug, potentiates fluoxetineinduced increases in dopamine levels via multireceptor actions in the rat medial prefrontal cortex. Neurosci Lett 364: $16-21$.

Zhang W, Perry KW, Wong DT, Potts BD, Bao J, Tollefson GD et al (2000). Synergistic effects of olanzapine and other antipsychotic agents in combination with fluoxetine on norepinephrine and dopamine release in rat prefrontal cortex. Neuropsychopharmacology 23: 250-262. 